\title{
A comparative analysis between atraumatic and conventional anesthetic techniques in surgical removal of upper third molars
}

\author{
Luís P. L. Donato', Marcela M. Maciel', Luiza M. Maciel', Lívia M. Lopes², \\ Alessandra de A. T. Carvalho², Hugo F. L. de Oliveira ${ }^{3}$ Hélder L. Rebelo² \\ 1. Centro de Ensino Superior Maceió; Graduação em Odontologia, Alagoas, Brasil. \\ 2. Universidade Federal de Pernambuco; Programa de Pós-Graduação em Odontologia, Pernambuco, Brasil. \\ 3. Universidade de Pernambuco; Programa de Odontologia, Pernambuco, Brasil.
}

\begin{abstract}
Pain control is essential in dental practice, and can be accomplished through various techniques. This study seeks to compare atraumatic and conventional anesthetic techniques, applied during surgeries to remove upper third molars. The endpoints evaluated were pain indices, patient satisfaction and anesthetic efficacy. A random parallel split-mouth clinical trial was conducted with 14 patients. Group A received atraumatic anesthesia without a needle (Comfort-in $\AA$ ) and group $B$ received conventional anesthesia by blocking the posterior superior alveolar nerve (PSAN) and Greater Palatine Nerve $(G P N)$. A Visual Analogue Scale (VAS) was used to assess pain.
\end{abstract}

A significantly $(p<0.001)$ lower perception of pain was observed among individuals who received the atraumatic technique. In $71 \%$ of cases, it was necessary to supplement the anesthesia during the procedure. Even considering the need for additional anesthesia, the Comfort-in $\mathbb{R}$ technique was more accepted by patients with regard to pain perception than the conventional manual technique.

Received: September 2020; Accepted: November 2020.

Keywords: anesthesia, dental - pain management - patient satisfaction.

\section{Análise comparativa entre a técnica anestésica atraumática e convencional em cirurgia para remoção dos terceiros molares superiores}

\section{RESUMO}

O controle da dor é fundamental na prática odontológica, podendo ser feito a partir de várias técnicas. Este estudo visa comparar as técnicas anestésicas atraumática e convencional, aplicadas durante cirurgias para remover terceiros molares superiores. Os pontos avaliados foram indice de dor, satisfação do paciente e eficácia anestésica. Um ensaio clínico randomizado, paralelo, boca dividida, foi conduzido com 14 participantes. O grupo A recebeu anestesia atraumática sem agulha (Comfort-in $\AA)$ e o grupo $B$ anestesia convencional por meio de bloqueio do nervo alveolar superior posterior (NASP) e nervo palatino maior (NPM). Uma Escala Visual Analógica (EVA) foi utilizada para avaliar a dor. Uma significativa $(p<0,001)$ menor percepção de dor entre os individuos que receberam a técnica atraumática foi observada. Em 71\% dos casos, fez-se necessária a complementação da anestesia durante a realização do procedimento. Mesmo considerando a necessidade de anestesia adicional, a técnica empregando o sistema Comfor$t$-in ${ }^{\circledR}$ teve maior aceitação dos pacientes quando comparado à técnica manual convencional, no que se refere a percepção de dor, ainda que considerando a necessidade de complementação da anestesia.

Palavras-chave: anestesia dentária - manejo da dor - satisfação do paciente.

\section{INTRODUCTION}

Surgical procedures are common in daily dental practice, and even with the advances in technique, equipment, drugs and materials in recent decades, there are still patients who are resistant to these types of treatment due to anxiety and fear ${ }^{1}$. Surgical

trauma can cause acutely painful symptoms in tissues, with patients reacting in different ways ${ }^{2}$.

Pain control through dental anesthesia is essential during dental practice. Local anesthetic solutions correspond to reversible blocking of nerve 
conduction, causing loss of sensation without altering the level of consciousness, with reversibility being a principal characteristic ${ }^{3-5}$.

Conventional anesthetic techniques are widely used in dental routine for their simplicity in application and great assertive power. However, they present a greater chance of patient anxiety and fear, mainly due to exposure to needles, which in most cases is associated with pain ${ }^{6,7}$.

The Comfort-in ${ }^{\circledR}$ system (Mika Medical; Busan, Korea) was created with the aim of achieving more comfortable anesthetic infiltration. In this system, defined as atraumatic, anesthetic is administered without a needle by pressure dosed in a fraction of a second. According to the manufacturer ${ }^{8}$, the absence of a needle during the execution of anesthetic technique in dental treatment can be associated with pain reduction, thereby reducing a patient's anxiety. Considering that pain and anxiety can contribute to the avoidance or delay of dental treatment in patients of all ages ${ }^{9}$, studies are needed to evaluate and compare painless anesthetic techniques with conventional techniques ${ }^{10}$. Therefore, this study seeks to compare atraumatic and conventional anesthetic techniques with respect to pain indices, patient satisfaction and anesthetic efficacy, in surgeries to remove upper third molars.

\section{MATERIALS AND METHODS}

This was a randomized parallel split-mouth clinical trial with the objective of comparing the Comfortin ${ }^{\circledR}$ system (Mika Medical; Busan, Korea) with conventional technique using carpule syringe and short needle (30 gauge) for local anesthesia, prior to surgery to remove upper third molars. The study was approved by the ethics committee of the Centro de Ensino Superior Maceió (Cesmac), under the CAAE protocol 91178518.9.0000.0039, with code RBR9qm2y5 (Brazilian Registry of Clinical Trials).

All participants were informed of research content and signed a free and informed consent form; they were also informed of the risks and benefits involved in participation in the research and were told that they could drop out of the research at any time without loss of treatment. The research took place at the Campus I Dentistry Clinic at Centro Universitário Maceió (Cesmac) located in the city of Maceió in the state of Alagoas, Brazil. A nonprobabilistic sample was selected from March to May 2019.
Fourteen individuals participated in the study, in which the posterior superior alveolar nerve and the greater palatine nerve of the right and left sides of palatal arch were anesthetized, totaling 56 blocks. Participants were chosen based on the following criteria: 18 to 45 years old, needing removal of the right and left third molars in symmetrical position, healthy, without any systemic pathologies, and without a history of anxiety and depression disorder. Participants were excluded when it was not possible to perform the projected anesthetic technique due to the specificities of surgical planning.

Immediately before surgery, a person not directly involved with the research project randomly determined which technique would be applied to each side of the arch by tossing a coin. Both upper third molars were removed during the same surgical session.

Each patient received an anesthetic solution (Articaine 4\% with epinephrine 1: 100.000, DFL) through the needle-free syringe with pressure and dosage controlled by the Comfort-in ${ }^{\circledR}$ atraumatic anesthesia system (group A). On the contralateral side, the participant received the same anesthetic solution through a conventional carpule syringe and $30 \mathrm{G}$ gingival needle under manual pressure (group B). The procedures for blocking the posterior superior alveolar and greater palatal nerve (Fig. 1) were performed in all patients by the same operator (FH).

Immediately after the anesthetic procedure, the patient was asked to rate their pain using a Visual Analogue Scale (VAS) ${ }^{11}$ followed by measurement of vital signs. The VAS consists of a line representing a continuous quality of intensity and verbal data - no pain to maximum pain. The size of the line may vary, but it is often $10 \mathrm{~cm}$. This scale produces level data at intervals, enabling the use of statistical parameters in the analysis.

Patient satisfaction level after an anesthetic block was assessed by asking the patient to evaluate the statements "I am satisfied after anesthesia" and "I think I'm anesthetized enough" on a 5-point Likert scale ${ }^{12}$ by selecting one of the following: strongly agree, agree, no opinion, disagree, or strongly disagree. The responses were recorded according to a consecutive number scale using scores from 1 to 5 . The need to supplement the anesthetic solution, the amount of anesthetic used, infiltration time, and the need for additional anesthesia while the surgery was performed were considered. 

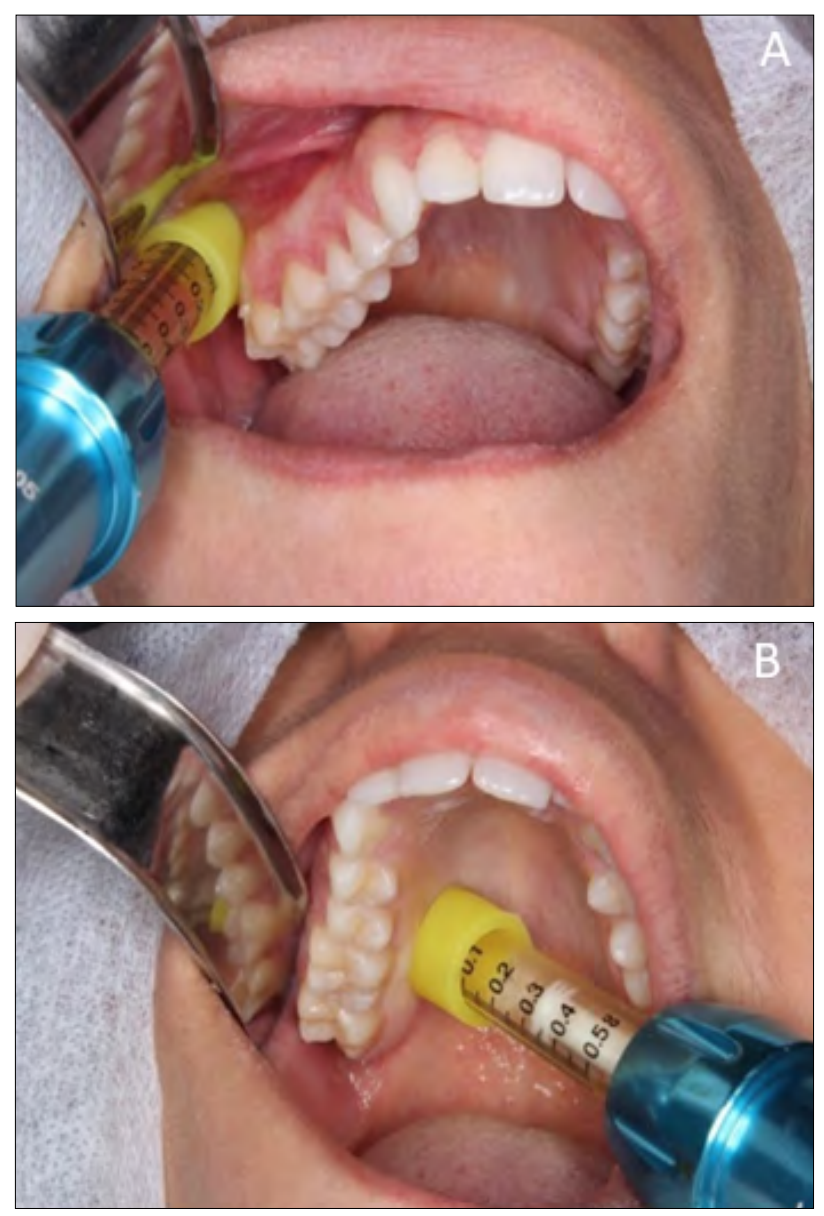

Fig.1: PSAN Anesthesia with Comfort-in ${ }^{\circledR}$ System A: posterior superior alveolar nerve. B: Greater palatal nerve.

\section{Data analysis}

A database was generated and analyzed using Microsoft Excel 2010 software, with the analysis including Student's t test and Pearson's chi-squared test for nominal variables. $p$ values lower than .05 were considered to be statistically significant.

\section{RESULTS}

A total 14 participants were selected for the study, with $64 \%$ being female and $36 \%$ male. Mean age of the sample was 23.42 years. VAS pain values show statistically significant differences between groups, with the group treated with the atraumatic technique (group A) reporting less pain than the group treated with the conventional manual technique (group B), both for superior alveolar nerve and greater palatine nerve.

Comparison of satisfaction values using the Likert Scale showed no significant difference between group A and group B (Table 1).

All participants treated with the conventional manual technique (Group B) reported sufficient anesthesia while patients anesthetized with the atraumatic technique (group A) needed an anesthetic supplement $(\mathrm{p}<0.0001)$. Of the fourteen cases anesthetized using this technique, ten (71\%) required supplemental anesthesia: two in NASP, three in NPM and five cases in both nerves.

\section{DISCUSSION}

Of the fourteen survey participants, $64 \%$ were female and $36 \%$ male. Average age was 23.4 years. As in the study by Aragão et al..$^{6}$, there was a higher prevalence of female individuals with similar average age. Females tend to have higher levels of anxiety regarding dental treatment ${ }^{2}$, which can interfere with the patient's perception of pain ${ }^{13}$.

The purpose of the Comfort-in ${ }^{\circledR}$ atraumatic system is to reduce discomfort during anesthesia. It is relatively new on the market, which explains the small number of published papers evaluating its effectiveness. In a recent publication, Oliveira et al. ${ }^{14}$ evaluated the effectiveness of anesthesia after the use of this atraumatic system, compared to the conventional technique, finding no statistically significant difference in relation to pain assessment using VAS after injection. The results of the present study, on the other hand, showed that participants who were anesthetized using the atraumatic system reported significantly less pain than those anesthetized using the conventional technique. This can be explained by the differences between the anesthetic techniques used in the two studies.

In the study by Oliveira et al. ${ }^{14}$, infiltrative anesthesia was used prior to the restoration of first permanent molars, which may have resulted in greater pain perception caused by the expansion of tissues after the infiltration of the anesthetic solution, even with slow administration speed. In this study, NASP and GPN regional blocking techniques were employed. There was no statistically significant difference between groups regarding patient satisfaction with the anesthetic techniques. Both were satisfied with the level of anesthesia achieved. All patients anesthetized using the conventional technique (Group B), considered it to be sufficient. When anesthetized using the atraumatic technique, on the other hand, $71 \%$ of cases requested supplementation of anesthesia.

In a study by Areias et al. ${ }^{15}$, comparing the efficacy of a classic local infiltration anesthesia with a 
Table 1. Pain perception and degree of satisfaction $(\bar{X} \pm S D ; n=14)$

\begin{tabular}{|c|c|c|c|c|}
\hline & & $\begin{array}{c}\text { Atraumatic } \\
\text { technique (group A) }\end{array}$ & $\begin{array}{c}\text { Conventional } \\
\text { technique (group B) }\end{array}$ & $\mathrm{p}$ value \\
\hline $\begin{array}{c}\text { Pain } \\
\text { Perception }\end{array}$ & $\begin{array}{c}\text { Posterior Superior } \\
\text { Alveolar Nerve (PSAN) }\end{array}$ & $1.50 \pm 1.40$ & $2.57 \pm 2.43$ & $0.041^{*}$ \\
\hline $\begin{array}{l}\text { Scale } \\
\text { (VAS) }\end{array}$ & $\begin{array}{c}\text { Greater Palatine Nerve } \\
\text { (GPN) }\end{array}$ & $1.28 \pm 1.58$ & $4.21 \pm 1.84$ & $0.001^{*}$ \\
\hline Degree of Satisfac & Scale) & $4.43 \pm 0.64$ & $4.63 \pm 0.49$ & $0.095^{\star}$ \\
\hline
\end{tabular}

needle-free anesthetic system - Injex ${ }^{\circledR}$ (Rösch, Berlin, Germany), in which 100 pediatric patients were treated, it was observed that in $68 \%$ of the cases in which Injex ${ }^{\circledR}$ was used, it was necessary to repeat the anesthesia, as in the present study.

The need to supplement the anesthetic solution of the Comfort-in ${ }^{\circledR}$ system may be related to the divergence between techniques in the amount of anesthetic used. Malamed ${ }^{16}$ recommends that the minimum amount of local anesthetic for the greater palatine nerve be 0.45 to $0.6 \mathrm{ml}$, while for the posterior superior alveolar nerve, it should be $1.8 \mathrm{ml}$ (1 tube). Each ampoule of the Comfort-in ${ }^{\circledR}$ system has a maximum capacity of $0.5 \mathrm{ml}$; for blocking the posterior superior alveolar nerve, a $0.5 \mathrm{ml}$ ampoule with a straight cap was used, while for the greater palatine nerve block, a $0.3 \mathrm{ml}$ ampoule with curved cap was used.

Another divergence between the techniques is related to the proximity at which the anesthetic liquid is placed. Malamed ${ }^{16}$ suggests that anesthetic liquid should be placed close to the main nerve trunk to be successful, with a penetration depth of approximately $16 \mathrm{~mm}$ for the posterior superior alveolar nerve and approximately $5 \mathrm{~mm}$ for the greater palatine nerve. The conventional technique probably enabled placement of a greater volume of anesthetic solution next to the main nerve trunk.

\section{ACKNOWLEDGMENTS}

The Brazilian National Council for Scientific and Technological Development (CNPq).

\section{FUNDING}

None.
Another negative point observed relates to the difficulty for the dentist to obtain a $90^{\circ}$ angle with the point to be anesthetized with the Comfort-in ${ }^{\circledR}$ system, which the manufacturer recommends during the execution of the technique.

As shown in the studies by Faraco Junior et al. ${ }^{17}$, Areias et al. ${ }^{15}$, Aragão et al. ${ }^{6}$ and Silveira et al. ${ }^{18}$ who used Morpheus ${ }^{\circledR}$ (São Paulo, São Paulo, Brazil), Injex ${ }^{\circledR}$ and The Wand ${ }^{\circledR}$ (Livingston, New Jersey, United States) atraumatic anesthetic injection systems respectively, the Comfort-in $\AA$ system showed a good level of acceptance by the participants, with a low level of pre-anesthetic anxiety and a low level of pain from the injection. Further studies are needed to for extra testing of the anesthetic effectiveness of the system.

\section{CONCLUSION}

Despite the limitations of this study, the data show that the technique employing the Comfort-in ${ }^{\circledR}$ system had a higher level of acceptance by patients than the conventional manual technique with regard to pain perception, even considering the need for supplementing anesthesia.

\section{Conflict of interest}

The authors have no conflict of interest to declare.

\section{CORRESPONDENCE}

Dr. Hélder Lima Rebelo

Av. Prof. Moraes Rego, 1235, Cidade Universitária Recife - PE, Brasil, 50670-901

rebelo_al@hotmail.com 


\section{REFERENCES}

1. Lin CS, Wu SY, Yi CA. Association between Anxiety and Pain in Dental Treatment: A Systematic Review and Metaanalysis. J Dent Res 2016;96:1-10.

2. Yakar B, Kaygusuz TÖ, Pırınçcı E. Evaluation of Dental Anxiety and Fear in Patients who Admitted to the Faculty of Dentistry: Which Patients are More Risky in terms of Dental Anxiety. Ethiop J Health Sci 2019;29:1029-1857.

3. Wolkerstorfer A, Handler N, Buschmann H. New approaches to treating pain. Bioorg Med Chem Lett 2016; 26:1103-1109.

4. Coté CJ, Brown Jr RE, Kaplan A. The Single-ClinicianOperator/Anesthetist Model for Dental Deep Sedation/ Anesthesia: A Major Safety Issue for Children. JAMA Pediatr 2019;172:1127-1128.

5. Mittal J, Kaur G, Mann HS, Narang S. et al. Comparative Study of the Efficacy of $4 \%$ Articaine vs $2 \%$ Lidocaine in Surgical Removal of Bilaterally Impacted Mandibular Third Molars. J Contemp Dent Pract 2018;19:743-748.

6. Aragão JMR, Amorim KS, Cunha RS, Groppo FC, de Ameida Souza LM. Comparison of pain level in the inferior alveolar nerve block through two different techniques. Rev Odontol UNESP 2016;45:322-326. https://www.scielo. br/scielo.php?pid=S1807-25772016005020101\&script $=$ sci _abstract

7. Aggarwal K, Lamba AK, Faraz F, Tandon S, Makker K. Comparison of anxiety and pain perceived with conventional and computerized local anesthesia delivery systems for different stages of anesthesia delivery in maxillary and mandibular nerve blocks. J Dent Anesth Pain Med 2018; 18:367-373.

8. Instruction Manual: Comfort-intm Needle Free Injection System. Mika Medical Co. 2019. http://www.comfort-in. com/file/English French\%20manual.pdf. Accessed April 10, 2019.

9. Milgrom P, Coldwell SE, Getz T, Weinstein P, Ramsay DS. Four Dimensions of Fear of Dental Injections. J Am Dent Assoc 1997;128:756-762.
10. Monteiro J, Tanday A, Ashley PF, Parekh S, Alamri H. Interventions for increasing acceptance of local anaesthetic in children and adolescents having dental treatment. Cochrane Database Syst Rev 2020;2:1-127.

11. Bijur PE, Silver W, Ma E, Gallangher EJ. Reliability of the Visual Analog Scale for Measurement of Acute Pain. Academ Emerg Med 2001;8:1153-1157.

12. Norman G. Likert scales, levels of measurement and the "laws" of statistics. Adv Health Sci Educ Theory Pract 2010;15:625-632.

13. Smyth JS. Some problems of dental treatment. Part 1. Patient anxiety: Some correlates and sex diferences. Aust Dent J 1993;38:354-359.

14. Oliveira ACA, Amorim KS, Nascimento Júnior EMD, Duarte ACB, Groppo FC, Takeshita WM, Souza LMA. Assessment of anesthetic properties and pain during needleless jet injection anesthesia: a randomized clinical trial. J Appl Oral Sci 2019;27:e20180-195.

15. Areias C, Macho V, Norton A, Macedo P, de Andrade C. Comparação de dois sistemas anestésicos. Revista da Ordem dos Médicos Dentistas 2011; 1: 8-12. https://www. omd.pt/content/uploads/2017/12/revistaomd09.pdf

16. Malamed SF.Techniques of Maxillary Anesthesia. In: Malamed SF, editor. Handbook of anesthesia local. $7^{\text {th }}$ ed. St. Louis, Missouri, USA: Saunders Elsevier, 2019:188224.

17. Faraco Júnior IM, Dable ALR, Ottoni AB Marquezan M, Ferreira Tovo M, Floriani Kramer P. Utilização do Sistema de AnestesiaComputadorizadaTheWand $\AA$ emOdontopediatria. Pesqui Bras Odontopediatria Clin Integr 2007;7:95-101. https://www.redalyc.org/pdf/637/63770113.pdf

18. Silveira MPM, Costa RA, Amorim KS et al. Avaliação da eficácia anestésica do Morpheus ${ }^{\circledR}$ através da técnica intrasseptal CaZOE na pulpotomia de dentes decíduos: estudo-piloto. Rev Odontol UNESP 2017;46:147-152. https://www.scielo.br/scielo.php?pid=S1807-25772017000 $300147 \&$ script $=$ sci_abstract\&tlng $=$ pt 